\title{
Ostrich Antibody and Its Application to Skin Diseases, a Review and Case Report
}

\author{
Yasuhiro Tsukamoto ${ }^{*}$, Osamu Maeda ${ }^{2}$, Genshi Shigekawa ${ }^{3}$, Stuart Greenberg ${ }^{4}$, Barry Hendler ${ }^{5}$ \\ ${ }^{1}$ Department of Animal Sciences, Graduate School of Environmental \& Biological Sciences, Kyoto Prefecture University, Kyoto, \\ Japan \\ ${ }^{2}$ Clinical Studies, Zeal Cosmetics, Osaka, Japan \\ ${ }^{3}$ Bioresearch Section, Maz World, Hong Kong Science Park, Hong Kong S.A.R., China \\ ${ }^{4}$ Clinical Studies, Ostri Gen Holdings, West Newton, MA, USA \\ ${ }^{5}$ Microfollicular Hair Transplantation, Ambler, PA, USA \\ Email: *ytsuka@kpu.ac.jp
}

How to cite this paper: Tsukamoto, Y., Maeda, O., Shigekawa, G., Greenberg, S. and Hendler, B. (2018) Ostrich Antibody and Its Application to Skin Diseases, a Review and Case Report. Health, 10, 1357-1370. https://doi.org/10.4236/health.2018.1010105

Received: September 26, 2018

Accepted: October 19, 2018

Published: October 24, 2018

Copyright $\odot 2018$ by authors and Scientific Research Publishing Inc. This work is licensed under the Creative Commons Attribution International License (CC BY 4.0).

http://creativecommons.org/licenses/by/4.0/

\begin{abstract}
Antibodies are immunoglobulins produced by B cells when antigens such as allergens or pathogens invade an animal's body. The antibodies remove and inactivate antigens. Antibodies are distributed in internal body and mucosal membrane to protect living animals, but they are excellent proteins that can exert their functions, "antigen-antibody reactions," even when removed from the body. For that reason, antibodies are being put to practical use in diagnostic kits for conditions such as pregnancy and influenza infection, and as anticancer drugs targeting specific tumor markers. The result has been an increasing use of antibodies for research, diagnosis, and therapeutic purposes. Unfortunately, antibodies from experimental mammals such as mice, rats, and rabbits, are not suited to industrial use because of their high production cost. Moreover, handling of these antibodies is difficult due to their vulnerability to heat, acids and alkalis. Accordingly, there is no adaptability to mass production. Recently, we developed a convenient method for the low-cost, mass-production of antibodies using egg-laying hen ostriches. The ostrich egg is an excellent source of antibodies for industrial purposes. The present report shows that the ostrich antibodies have therapeutic effects in ailments such as atopic dermatitis, acne, pyoderma, and pollen allergies. We have successfully produced and purified ostrich immunoglobulin yolk (IgY) against pollen allergens (Cryj1, Cryj2, Chao1, Chao2) and found that allergic reactions were alleviated in skin patch tests of allergic patients by using the ostrich IgY. In addition, we produced ostrich IgY against the homogenates of Staphylococcus aureus and Propionibacterium acnes, and applied to dermal lesions of atopic dermatitis and acne patients, and then observed the therapeutic effects on the dermatitis of volunteer subjects. Antibody against $S$. au-
\end{abstract}


reus also had the therapeutic effect on canine pyoderma caused by MRSA. A particular advantage in using ostrich antibodies is the fact that they inactivate and neutralize a specific antigen, without damaging the indigenous microflora of the dermal surface. In this review article and case repot, we wish to suggest that ostrich antibodies can contribute to the treatment of cutaneous disorders as an alternative to treatment with steroids or antibiotics.

\section{Keywords}

Ostrich Antibody, Cosmetics, Atopic Dermatitis, Acne, Pollen Allergy, Pyoderma

\section{Introduction}

Antibodies have become an important focus in post genome research. They are being applied in a wide range of therapeutics and diagnosis. Antibodies are proteins produced from B-lymphocytes when antigens invade the body. They remove and inactivate foreign substances together with various agents, including complements. Antibody production is particularly important for infectious diseases. For example, the aim of vaccination is to produce in advance specific antibodies in the body to prevent, or reduce the virulence of, a specific infectious disease. A great feature of antibodies is their "specificity," which means they bind only to specific factors. Moreover, because they can exert their binding function even when removed from a living body, they are used as diagnostic agents for detecting specific molecules [1].

Demand for diagnostic agents of infectious diseases such as influenza and for malignant tumors has been on the rise, with a resulting increase in demand for antibodies. Animals are always necessary for the production of antibodies. Small animals such as mice and rabbits are mainly used, but sometimes larger animals such as goats and horses are used. These animals are normally inoculated with antigens to produce antibodies in the body, and the antibodies are then purified from the blood. Techniques for producing monoclonal antibodies by hybridomas, using splenocytes, have also been established, generally by using mice. In any case, animals are inevitably sacrificed to obtain the antibodies. Furthermore, the amounts of antibodies obtained are small, and the production cost is surprisingly high. As a result, the use of antibodies is limited to research and expensive medical treatment. Beyond the cost of antibody production, there are serious issues of animal welfare. It should also be noted that antibody proteins are inactivated by heat, acids, and alkalis, preventing mass commercial production. We have tried to solve these disadvantages of antibodies. We have overcome these problems by using ostrich eggs and have found a new way to use antibodies: ex. our research group has developed various ostrich antibodies suitable for the prevention of infection by pathogenic microorganisms and adapting them for prevention and treatment of infection [2] [3] [4] [5] [6]. Furthermore, we have 
been developing materials for defense against infection using ostrich antibodies [7]. In a single step, we explored a method of inhibiting only specific pathogens and molecules without destroying the resident microflora present in human and animal skin, gastrointestinal tract, etc. by utilizing the advantage that antibody has specificity to antigen [8]. We believe that these trials will greatly broaden the field of application of conventional antibodies.

In this article we discuss the practical application of ostrich antibodies, by which means we have established low-cost mass-production technology to create skin care raw materials.

\section{Ostrich Antibodies}

The ostrich (Struthio camelus) is the largest bird species on the planet, with males reaching heights of $250 \mathrm{~cm}$ and weighing more than $160 \mathrm{~kg}$. They are also the fastest biped animals, achieving speeds of $60 \mathrm{~km} / \mathrm{h}$. Ostrich eggs weigh approximately $1.5 \mathrm{~kg}$ and are 25 to 30 times the size of chicken eggs, with superior hens laying approximately 100 eggs per year. Their lifespan is said to be over 60 years (Figure 1). Ostriches are raised primarily for food and leather in Japan, but they are not easy to approach and manage due to their ferocity.

We first began breeding ostriches to deal with a "bean sprout" problem. Food surpluses such as tofu refuse and bean sprouts are industrial waste, requiring high cost incineration due to their large moisture content. In order to solve this problem, we fed ostriches a lot of tofu refuse and bean sprouts. The result was a drastic reduction in surplus food by as much as $2-3$ tons a day, along with a corresponding cost reduction for collaborating food companies. Moreover, since ostrich feces lack moisture and odor, they are useful as fertilizer for cultivating leeks and the like. We aim to cultivate environmentally friendly animals in this way.

In the course of studying ostriches, we noticed their high level of immunity

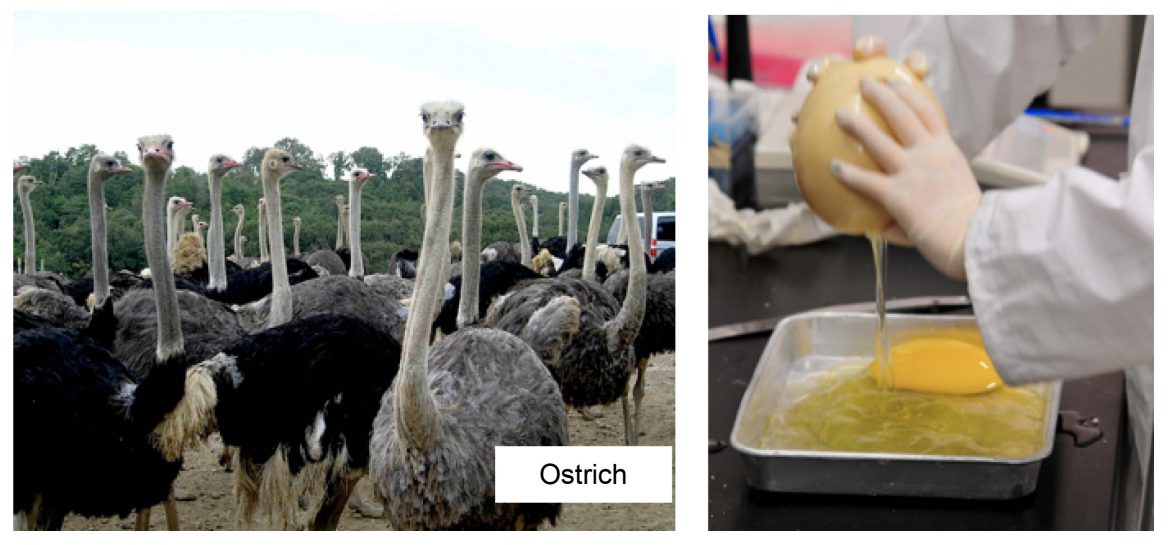

Figure 1. Ostriches are the largest existing birds on the planet, reaching a height of $2 \mathrm{~m}$ $50 \mathrm{~cm}$ and weighing more than $160 \mathrm{~kg}$. They are also the fastest biped animals, achieving speeds of $60 \mathrm{~km} / \mathrm{h}$. Their lifespan is said to be over 60 years and they continue laying eggs for at least 50 years. Ostrich eggs weigh approximately $15 \mathrm{~kg}$ and 25 to 30 times the size of chicken eggs. 
and conceived the idea of using ostriches as an "antibody production plant." The following is an overview of the development and results of the ostrich antibody that we actually performed. Birds have immune systems that protect chicks from pathogens by moving antibodies from the blood into their eggs [2] [9] [10] [11] [12]. Ostriches produce huge eggs. Furthermore, because their life expectancy is surprisingly as long as 60 years or more, we thought that it would be possible to continuously obtain large amounts of antibodies from eggs for a long period of time, if we had ostriches that produce superior antibodies. Upon immunizing an ostrich with an antigen, a sufficient amount of antibodies was found in the blood after approximately two weeks, resulting in the discovery that the antibodies efficiently migrated from the blood to the egg (especially the egg yolk) [2]. The ostrich antibodies accumulating in egg yolk are immunoglobulin yolk (IgY), which is almost the same as mammalian IgG, except that they are characterized by an extremely long $\mathrm{Fc}$ fraction (Figure 2). By making full use of our own immunization program and antibody purification method, we succeeded in developing a technology to obtain about 400 grams of IgY of high purity (more than 99\%) from a single ostrich over a period of 6 months to 1 year [2]. Antibodies were collected only from produced eggs, sparing the ostrich's life (Figure 3). The amount of antigen inoculated into an ostrich is the same as that inoculated into a rabbit or chicken, minimizing the cost of immunizing with an expensive antigen such as a recombinant protein. Furthermore, even under severe acidic conditions ( $\mathrm{pH} 4$ ) and $120^{\circ} \mathrm{C}$ for 5 minutes, the antigen-antibody reactivity of ostrich antibodies is stable at a high level, making it possible to adapt to many product production lines. Ovalbumin, a likely cause of egg allergies, is removed by our ostrich antibody purification method. As a result of the advantages we have discussed, antibodies can be produced at a cost approximately $1 / 4000$ of the

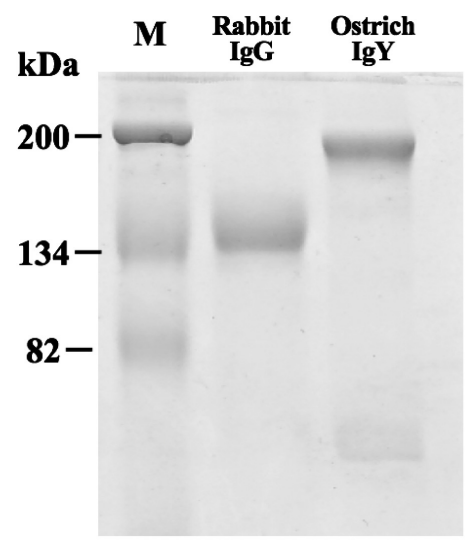

(a)

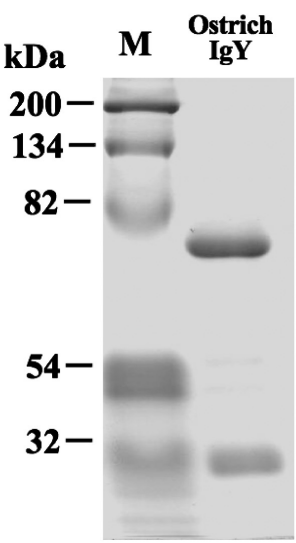

(b)

Figure 2. Ostrich egg yolk antibody (lgY). (a): Electrophoretic images of rabbit $\operatorname{lgG}$ and ostrich $\operatorname{lgY}$ (SDS-PAGE). The molecular weight of ostrich $\lg \mathrm{Y}$ is larger than rabbit $\operatorname{lgG}$ due to the long Fc fraction (approx. $200 \mathrm{kDa}$ ). (b): Heavy chain and light chain of ostrich $\operatorname{lgY}$ (under reduced SDS-PAGE). Excerpt from Adachi K et al., Mol Med Rep, 1: 2003-2009, 2008. 


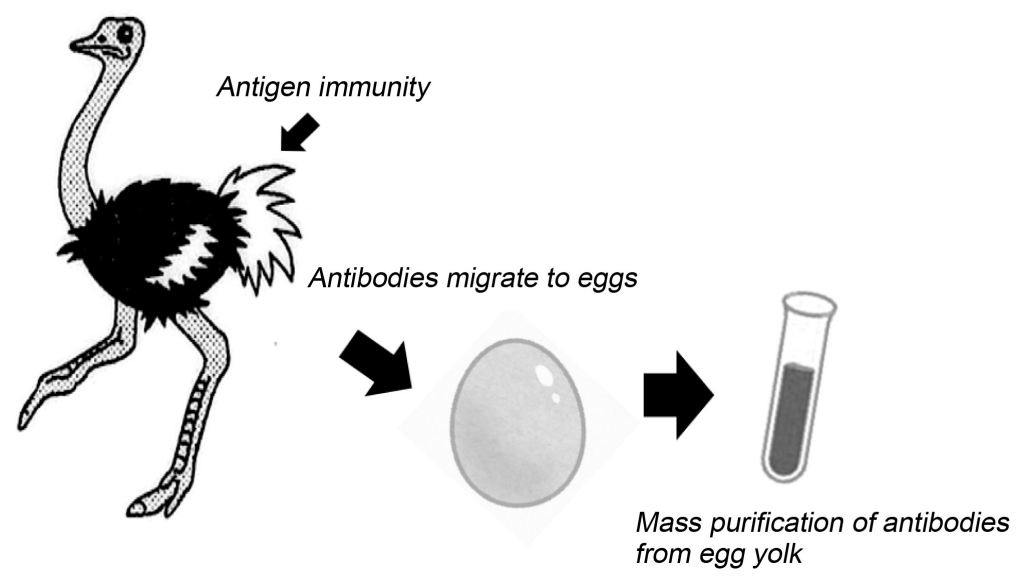

Figure 3. Method for producing ostrich antibodies. About $4 \mathrm{~g}$ of antibodies (purity: 99\% or more) is purified from the egg yolk of ostrich eggs in large quantities at low cost. Ovalbumin is not detected in the final purified solution (ELISA method). Because only eggs are used, the ostrich's life is not sacrificed.

conventional cost. Further, because the lot variation of products becomes extremely small, the field of application for antibodies can be dramatically expanded. We have constructed an ostrich research building, complete with artificial lighting and epidemic prevention system, and are currently producing antibodies in the building from 500 separately bred female ostriches.

Although we are developing various therapeutic and diagnostic agents using ostrich antibodies, we are also leveraging the advantages of "low cost" and "large quantity" to apply the antibodies to mass consumption type products. We have so far succeeded in mass-producing neutralizing antibodies against various influenza viruses, verifying that neutralizing activity is high against highly pathogenic avian influenza virus $\mathrm{A} / \mathrm{H} 5 \mathrm{~N} 1$ and swine influenza virus $\mathrm{A} / \mathrm{H} 1 \mathrm{~N} 1$, as well as seasonal influenza viruses, based on infection experiments using cultured cells, embryonated chicken eggs, and animals [2] [3] [4] [5]. Filters impregnated with ostrich antibodies against various influenza viruses and carried on nonwoven fabrics, have been commercialized for masks and space purifiers through the joint development of industry, academia, and government collaboration and are used in many medical institutions, etc. [7]. Interestingly, about 80,000 antibody masks are produced using a single ostrich egg. In addition, we have reported the protection against $\mathrm{A} / \mathrm{H} 5 \mathrm{~N} 1$ influenza and infectious bronchitis, a corona virus infection, using ostrich antibodies [2] [6]. Thus, we have focused on applying the utility of ostrich antibodies to a broader field.

\section{Application of Ostrich Antibodies for Skin Diseases}

Symbiotic relationship with bacteria is extremely important for many animals including humans. In particular, the presence of resident microflora in the skin and gastrointestinal tract is essential for maintaining health and the prevention of invasion by pathogens. Disruptions to the indigenous bacterial balance poten- 
tially cause or incentivize various diseases [13] [14]. Because disinfectants, antimicrobial agents, and antibiotics do not have specificity for the pathogen of interest, use of these agents also causes deterioration of the resident microfloraenvironment and can induce microbial substitution. Therefore, focusing on the merit of "specificity" of antigen-antibody reactions, we are adapting ostrich antibodies for skin diseases [8] [15]. Skincare products such as cosmetics can be kept in high temperature and acidic conditions in production steps such as stirring with base material, but ostrich antibodies can maintain their activity. Also, by using an appropriate substrate, ostrich antibody activity can be stable for at least 3 years at room temperature. We would like to describe the research on atopic dermatitis, acne, pyoderma, and pollen allergens, as shown below.

\subsection{Treatment for Pollen Allergens}

Our research group discovered that antibodies against pollen allergens were produced in ostriches [8]. It was found that antibodies purified from ostrich eggsreacted with cedar pollen allergens (Cryj1 and Cryj2) and cypress pollen allergens (Chao1, and Chao2), the cause of hay fever (Figure 4). Subsequently, we conducted a skin patch test among volunteers suffering from Japanese cedar pollinosis, using this ostrich antibody-containing filter, and found that the allergic reactions by pollen allergens Cryj1, Cryj2, Chao1 and Chao2 were suppressed (Figure 5). The reason for this appears to be that the binding of human IgE and the accompanying allergic reaction process is suppressed because the ostrich antibodies, which are polyclonal, mask the allergen molecules. Consequently, we have developed skin care products containing these antibodies extracted from

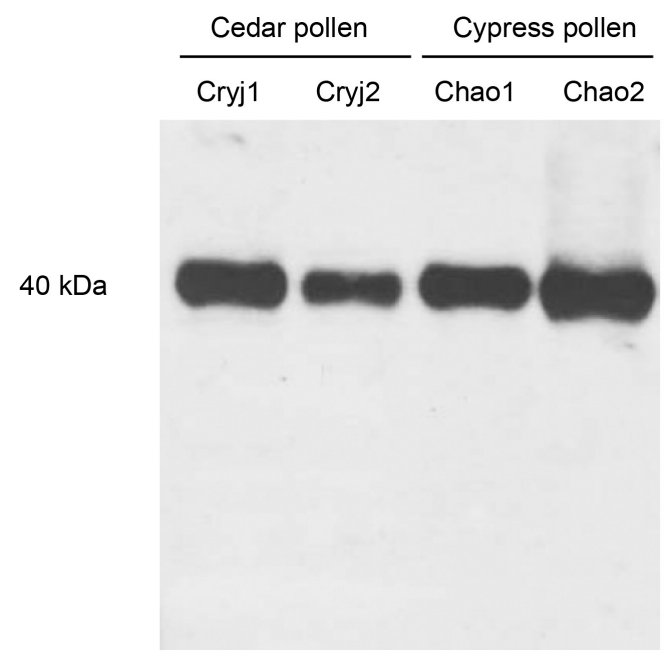

Figure 4. Reactivity of ostrich antibodies against pollen allergens (Western Blot Analysis). The antibodies extracted from the egg yolk of an ostrich with pollinosis react strongly against Cryptomeria pollen allergens Cryj1 and Cryj2 as well as Cypress pollen allergens Chao1 and Chao2. Excerpt from Tsukamoto et al., Frag J, 6: 36-41, 2013. 

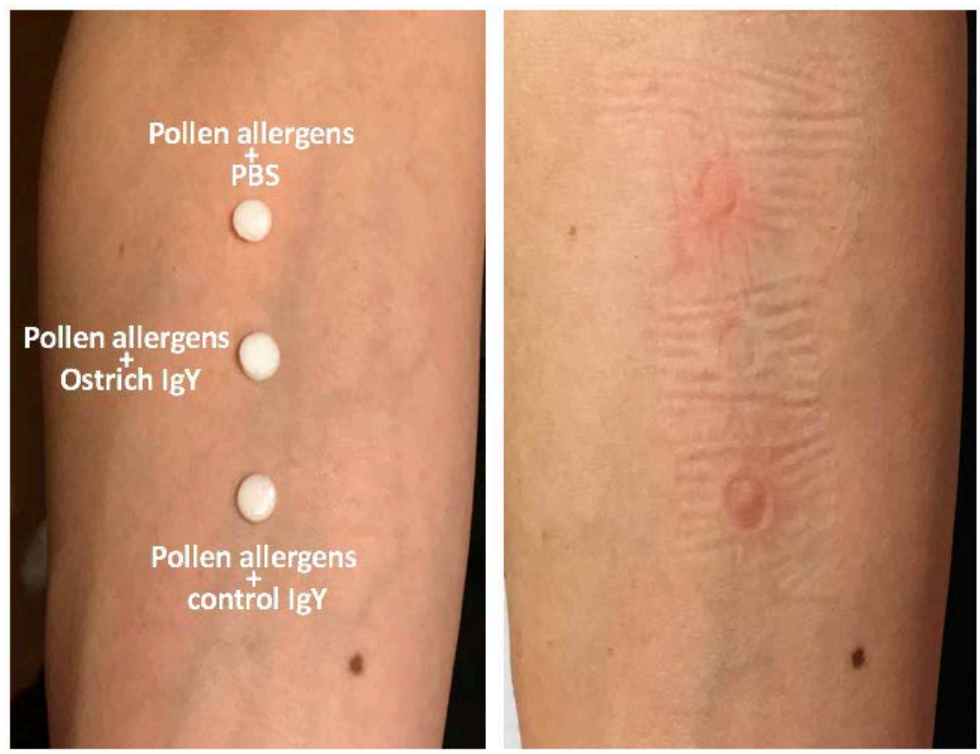

Figure 5. Patch test of cedar pollen allergens using ostrich antibodies. A circular filter containing cocktail of pollen allergens (Cryj1, Cerj2, Chao1 and Chao2) was attached to the interior part of the forearm of patients with pollinosis in order to determine the presence or absence of an allergic reaction after 1 hour. Although redness symptoms were observed in the pollen allergen filter, the symptoms were alleviated by the addition of ostrich antibodies. It was found that ostrich antibodies suppressed the skin's allergic reaction to pollen allergens. Traces of bandages still remain in all three sites.

the eggs of ostriches. In the form of a gel mist type, this product aims to inactivate pollen allergens in the skin, especially around the nose and eyes. It has been proven that the antigen-antibody reaction of pollen and ostrich antibodies has actually occurred on the skin surface upon ostrich antibody application (Figure $6)$.

\subsection{Treatment for Atopic Dermatitis and Acne}

We have succeeded in producing ostrich antibodies against Staphylococcus aureus ( $S$. aureus), toxins, and enzymes, which are regarded as factors that exacerbate atopic dermatitis [8] [16]-[22]. The obtained antibodies had a growth inhibitory effect on $S$. aureus (Figure 7) and were further found to exhibit high reactivity to enterotoxins, TSST-1, coagulase, and protease (Table 1) [14]. These toxins and enzymes induce itching and redness among sufferers from dermatitis, and we hoped that inactivation by ostrich antibody binding would lead to a reduction in symptoms. It is assumed that acne is formed due to the inflammation of hair follicles caused by interaction of bacteria and sebum. It has been pointed out that Propionibacterium acnes (P. acnes) [14] [23] and S. aureus (and toxins thereof) present in the skin are aggravating factors. Accordingly, we createdostrich antibodies specific to $P$. acnes and the bacterial homogenates, leading to success in suppressing the growth of the bacteria [8]. We then examined the usefulness of ostrich antibodies against $S$. aureus and $P$. acnes (including toxins 

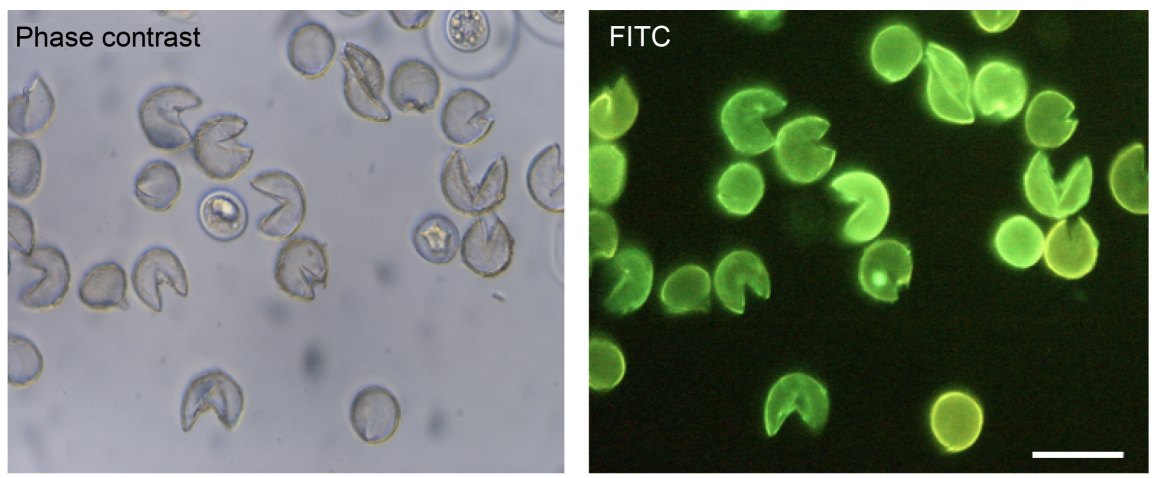

Figure 6. Antigen-antibody reaction of ostrich antibodies and cedar pollen on the skin surface (Immunofluorescence antibody method). Cedar pollen was adhered to the skin after the application of cosmetic products containing ostrich antibodies. The skin was washed 10 minutes later, after which, upon centrifuging the washing solution, the pollen was collected in order to observe via the immunofluorescent antibody method (FITC labeled antibodies). Specific fluorescence was observed in the obtained pollen, revealing that the "antigen-antibody reaction" of pollen and ostrich antibodies occurred on the skin surface. Bar, $50 \mu \mathrm{m}$.

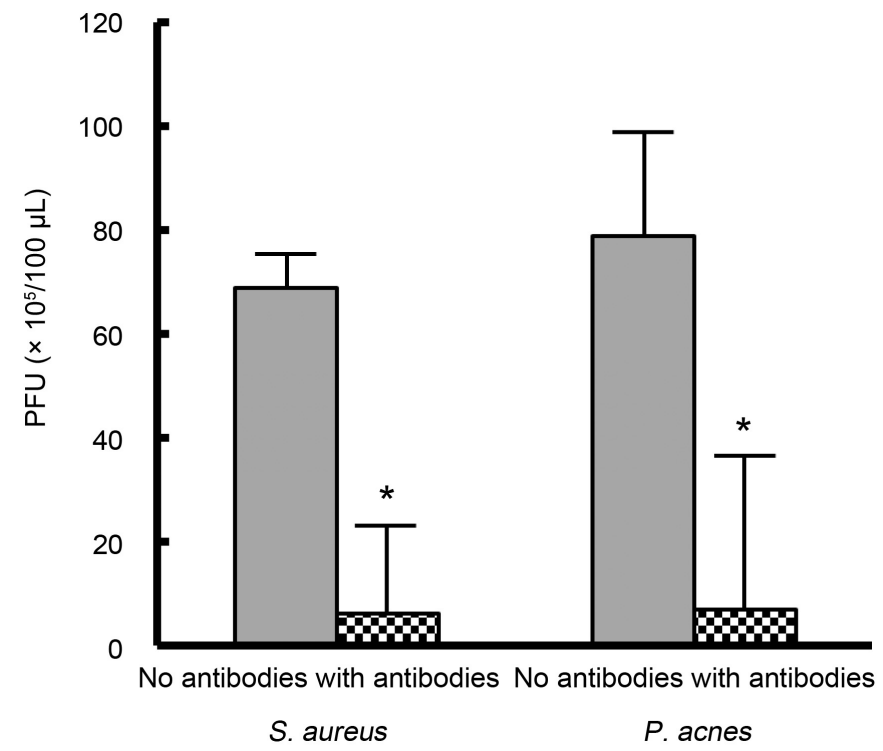

Figure 7. Suppression of the growth of $S$. aureus and $P$. acnes by ostrich egg yolk antibodies. It was found that ostrich antibodies suppress the growth of $S$. aureus and $P$ acnes. PUF was determined; the examination was performed in 5 petri dishes, and the average score and standard deviation were calculated. ${ }^{\star} P<0.01$ compared with the control (Student's $t$-test). Excerpt and modified from Tsukamoto et al., Frag J, 6: 36-41, 2013.

and enzymes). We have also succeeded in producing a base with high moisturizing ability, which is capable of holding ostrich antibody function for a long period of time. The result is the preparation of a stable ostrich antibody solution targeting atopic dermatitis and acne. Questionnaire surveys at dermatologist offices and medical esthetics clinics, etc. revealed that symptoms of atopy and acne 
Table 1. Reactivity of ostrich antibodies against $S$. aureus and toxins/enzymes (ELISA).

\begin{tabular}{|c|c|c|c|c|c|}
\hline \multirow[t]{2}{*}{ Antibody } & \multicolumn{5}{|c|}{$\begin{array}{c}\text { The antibody titer of ostrich egg yolk antibodies against } S \text {. aureus } \\
\text { and toxin/enzyme (EUSA) } \\
\text { (the highest dilution ratio was twice or more the absorbance } \\
\text { value of the pre-immune antibodies) }\end{array}$} \\
\hline & $\begin{array}{l}\text { S. aureus } \\
\text { bacteria }\end{array}$ & enterotoxins & TSST- 1 & Coagulase & Protease \\
\hline $\begin{array}{l}\operatorname{IgY} \text { from female } \\
\text { ostrich immunized } \\
\text { with } S \text {. aureus } \\
\text { homogenates }\end{array}$ & 6400 & 12,800 & 51,200 & 51,200 & 102,400 \\
\hline
\end{tabular}

It was revealed that the produced ostrich antibody produces high titer antibody against not only bacterial cells but also enterotoxins, superantigen TSST-1, coagulase, and protease. The toxins and enzymes mentioned above are factors that induce the deterioration of lesions by $S$. aureus, making it is very interesting that highly sensitive antibodies against them can be easily obtained. Excerpt and modified from Tsukamoto et al., Frag J, 6: 36-41, 2013.

were reduced (Table 2, Figure 8, Figure 9) [8]. In particular, with atopic dermatitis, many responded that the amount of scratching decreased due to reduced itching. While steroids and antibiotics are normally used for atopy and acne [19] [21] [23], we believe that a new concept of treatment was born, that is, using ostrich antibodies to suppress specific pathogens and toxins, without adversely affecting the resident microflora.

\subsection{Treatment of Pyoderma}

Pyoderma is a skin disease mainly caused by Staphylococcus and Streptococcus invading the skin from the outside, causing suppuration changes [24] [25] [26]. This disease is frequently observed in humans and dogs, and it is assumed that toxins and enzymes from the bacterial body, in addition to the infection and proliferation of the above bacteria, exacerbate the condition. While antibiotics are mainly used for treatment, this becomes difficult when multidrug-resistant bacteria such as MRSA are the causative bacteria. Subsequently, anti- $S$. aureus antibodies produced from ostriches were applied to dogs that had developed pyoderma due to MRSA infection. As a result, it took approximately two weeks until the symptoms subsided; however, the skin lesion substantially normalized (Figure 10). Histopathologically as well, inflammatory purulent dermatitis was cured. So far four dogs have been treated, and three showed improvement. While it is assumed that the one case in which improvement was not observed was due to a pathogen that was not $S$. aureus, tracking the details will be a future task. Going forward, verification with human pyoderma is planned and wider applications to humans and animals are expected.

\section{Conclusion and Future Prospects for Ostrich Antibodies in Skin Diseases}

The mainstream method for producing antibodies is mainly using small experimental animals such as mice and rabbits. Mice are used when producing 
Table 2. Questionnaire survey on cosmetics containing ostrich antibodies to volunteer subjects (efficacy rate).

\begin{tabular}{ccc}
\hline $\begin{array}{c}\text { Antibody Name } \\
\text { (Ostrich antibodies to the following antigens } \\
\text { were produced by immunization) }\end{array}$ & \begin{tabular}{c} 
Efficacy Rate (\%) \\
\cline { 2 - 3 } Eczema symptoms
\end{tabular} & $\begin{array}{c}\text { Relief of acne } \\
\text { symptoms }\end{array}$ \\
\hline $\begin{array}{c}\text { S. aureus } \text { system antibodies } \\
\text { (including toxins and enzymes) } \\
\text { Acne bacterial antibodies }\end{array}$ & 73 & 69 \\
$\begin{array}{c}\text { Mixture of } S \text {. aureus system antibodies } \\
\text { (including toxins and enzymes) } 8 \\
\text { Acne bacterial antibodies }\end{array}$ & 81 & 59 \\
Basement material only & 16 & Not yet performed \\
\hline
\end{tabular}

Ostrich egg yolk antibodies were mixed in a cosmetic base and applied to the affected part of the volunteer. The condition of the affected part at the first week (daily use) was observed. Basement material was used for comparison. Excerpt and modified from Tsukamoto et al., Frag J, 6: 36-41, 2013.

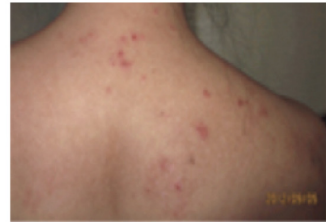

before

(a)

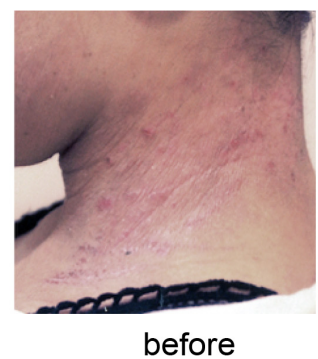

(b)

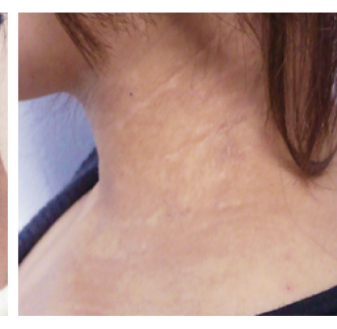

3-months

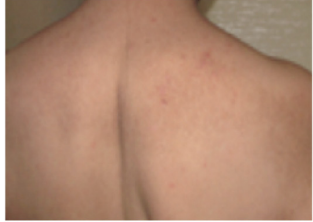

3-weeks

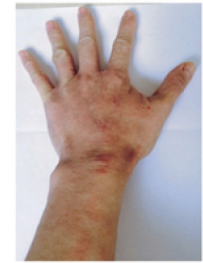

before

(c)

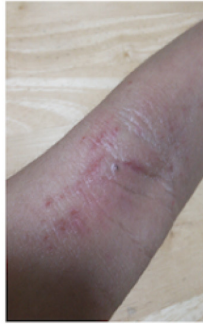

before

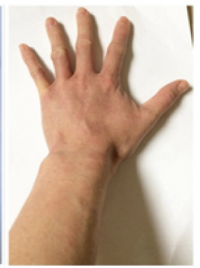

3-weeks

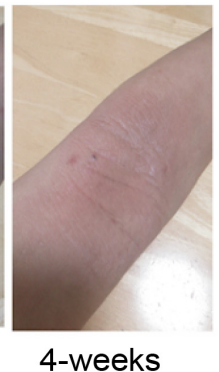

(d)

Figure 8. Application examples of cosmetic products containing ostrich antibodies for $S$. aureus (including toxins, enzymes) to atopic dermatitis. The subjects were instructed to use the material containing anti- $S$. aureus $(150 \mathrm{ug} / \mathrm{mL})$ daily for 3 months. The symptoms of atopic dermatitis were reduced in lesions by using material. (a) Dorsal shoulder (32 years old, woman); (b) cervical skin (30 years old, woman); (c) dorsal hand sikin (35 years old, woman); (d) interior elbow skin (38 years old, woman).

monoclonal antibodies. The hybridoma cells are established using myeloma cells and splenocytes from immunized mice, and antibody is collected from ascites or culture media. Although monoclonal antibodies have high specificity to antibo$\mathrm{dy}$, they take a long time to prepare, and the production cost is very high. In addition, since the epitope to be recognized is limited, it often happens that monoclonal antibody is not practical in the neutralizing activity of pathogens. Rabbits are mainly used for polyclonal antibody production. We get blood sample 


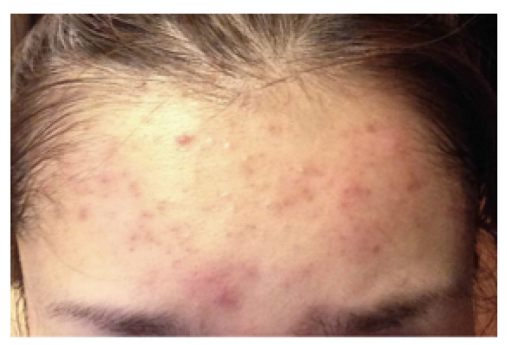

before

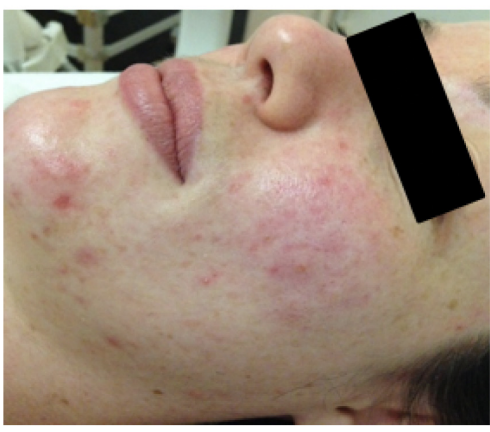

before

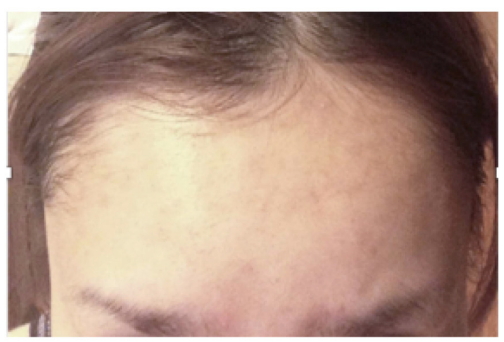

2-months

(a)

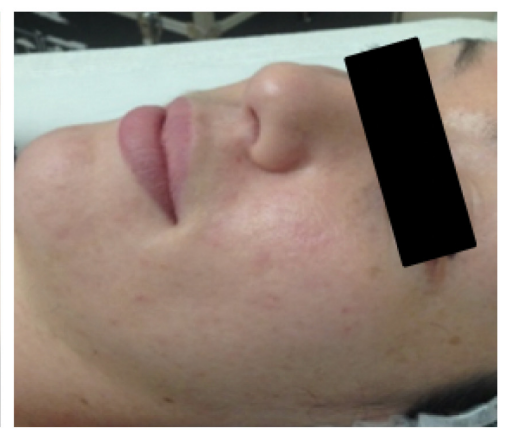

2-months

(b)

Figure 9. Application examples of cosmetic products containing ostrich antibodies for $S$. aureus (including toxins, enzymes) and $P$. acnes. The subjects were instructed to use the material containing anti- $S$. aureus $(150 \mathrm{ug} / \mathrm{mL})$ and anti- $P$. acnes $(150 \mathrm{ug} / \mathrm{mL})$ daily for 2 months. The symptoms of acne were reduced in lesions by using material. (a) Forehead skin (26 years old, woman); (b) facial skin (26 years old, woman).

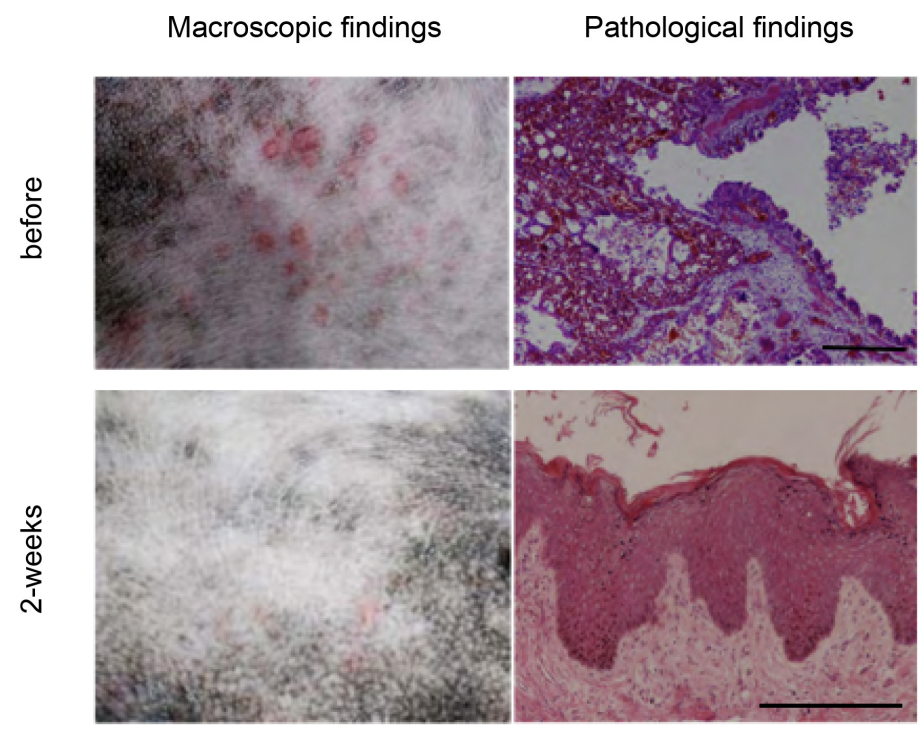

Figure 10. Application to canine skin diseases (pyoderma). Effects of ostrich antibodies (Anti-S. aureus) in the canine pyoderma caused by MRSA Infection (Dalmatian, 2 years old). The application of the ostrich antibodies to the trunk for 2 consecutive weeks led to a reduction in elevated redness of the skin. Histopathologically, remarkable inflammation, bleeding, and epidermal necrosis were regenerated in the tissue of the skin that was substantially normalized. Bars, $200 \mu \mathrm{m}$. 
from rabbits immunized rabbits and separate antisera. Antibodies are frequently purified from the blood, but when using Protein A etc., the cost of purification increases. In any case, antibody production using mammals often sacrifices the life of animals. There is avian IgY as an excellent method for producing antibodies, but in the case of ostrich in particular, large amounts of IgY can be purified from one ostrich, it is possible to minimize lot difference. Also, because it is resistant to heat and acid, it is suitable for introducing mass consumption type products into production lines. As a disadvantage of using an ostrich, it is not easy to approach and immunize them because they are huge and ferocious. When using an ostrich, you must learn veterinary procedures by disseminating their behavior and anatomy etc.

In addition to the case of $S$. aureus, $P$. acnes, and pollen allergens, we are also making and applying ostrich antibodies to several other antigens. For example, ostrich antibodies against house dust and various mites are being developed as preventive allergy treatments. We also believe that skin care products against ceramidase and Pseudomonas aeruginosa ( $P$. aeruginosa) can contribute to retention of the skin barrier. In order to prevent sexually transmitted diseases, practical use and verification of lubricants and contraceptive devices, using anti-HIV, anti-human herpes virus, anti-HPV, anti-syphilitic treponema, and anti-chlamydia neutralizing antibodies, are also under way. Some excellent results have been achieved in the area of androgenic alopecia (AGA)-male pattern and female pattern baldness. It is well-known that the hormone dihydrotestosterone (DHT) and the catalyst $5 \alpha$-reductase are involved in AGA. Ostrich antibodies to DHT and $5 \alpha$-reductase have been created. These antibodies were mixed with antibodies to $S$. aureus and $P$. aeruginosa to form the basis of a topical treatment. Initial testing has shown re-establishment of hair growth in all cases.

As described above, defining the purpose of use and preparing ostrich antibodies against target antigens will make it possible to develop a wide range of functional skin care products.

\section{Acknowledgements}

We thank Dr. Kazuhide Adachi, Mrs. Hatsuki Matsunaga and Miss Saaya Ueno at Kyoto Prefecture University for their technical supports.

\section{Conflicts of Interest}

The authors declare that there is no conflict of interest that could be perceived as prejudicing the impartiality of the research reported.

\section{Funding}

This study was supported in part by an innovation grant from Public Interest Incorporated Foundation KYOTO Industrial Support Organization 21.

\section{References}

[1] Gavilondo, J.V. and Larrick, J.W. (2000) Antibody Engineering at the Millennium. 
Biotechniques, 29, 128-132. https://doi.org/10.2144/002910v01

[2] Adachi, K., Takama, K., Ozaki, M., Fukuda, K., Endo, I., Yamamoto, R. and Tsukamoto, Y. (2008) Inhibition of H5N1 Avian Influenza Virus Infection by Ostrich Antibodies. Molecular Medicine Reports, 1, 2003-2009.

[3] Tsukamoto, M., Hiroi, S., Adachi, K., Kato, H., Inai, M., Konishi, I., Tanaka, M., Yamamoto, R., Sawa, M., Handharvani, E. and Tsukamoto, Y. (2011) Antibodies against Swine Influenza Virus Neutralize the Pandemic Influenza Virus A H1N1. Molecular Medicine Reports, 4, 209-214. https://doi.org/10.3892/mmr.2011.410

[4] Adachi, K., Takama, K., Tsukamoto, M., Inai, M., Handharyani, E., Hiroi, S. and Tsukamoto, Y. (2011) Ostrich Produce Cross-Reactive Neutralization Antibodies against Pandemic Influenza Virus A/H1N1 Following Immunization with a Seasonal Influenza Vaccine. Experimental and Therapeutic Medicine, 2, 41-45. https://doi.org/10.3892/etm.2010.180

[5] Adachi, K., Kato, T., Kirimura, N., Kubota, Y., Shiba, H. and Tsukamoto, Y. (2014) Double Infections with Avian $\mathrm{A} / \mathrm{H} 5 \mathrm{~N} 1$ and Swine $\mathrm{A} / \mathrm{H} 1 \mathrm{~N} 1$ Influenza Viruses in Chickens. American International Journal of Biology, 2, 58-94. https://doi.org/10.15640/aijb.v2n3-4a6

[6] Tsukamoto, Y., Nakano, Y. and Adachi, K. Protection against Infectious Bronchitis Virus, a Corona Virus Infection, Using Ostrich Antibodies. Health (in press).

[7] Kamiyama, Y., Adachi, K., Handharyani, E., Soejoedono, R.D., Kusano, T., Inai, M., Tsukamoto, M., Kashiwagi, S. and Tsukamoto, Y. (2011) Protection from Avian Influenza H5N1 Virus Infection with Antibody-Impregnated Filters. Virology Journal, 8, 54 (online).

[8] Tsukamoto, Y., Nishiura, K. and Maeda, O. (2013) Development of Functional Skin-Care Products Using Ostrich Antibodies. Fragrance Journal, 6, 36-41.

[9] Hamal, K.R., Burgess, S.C., Pevzner, I.Y. and Erf, G.F. (2006) Maternal Antibody Transfer from Dams to Their Egg Yolks, Egg Whites, and Chicks in Meat Lines of Chickens. Poultry Science, 85, 1364-1372. https://doi.org/10.1093/ps/85.8.1364

[10] Schade, R., Pfister, C., Halatsch, R. and Henklein, P. (1991) Polyclonal IgY Antibodies from Chicken Egg Yolk. An Alternative to the Production of Mammalian IgG Type Antibodies in Rabbits. ATLA, 19, 403-419.

[11] Schade, R., Schniering, A. and Hlinak, A. (1992) Polyclonal Avian Antibodies Extracted from Egg Yolk as an Alternative to the Production of Antibodies in Mammals-A Review. ALTEX, 9, 43-56.

[12] Zhang, X., Calvert, R.A., Sutton, B.J. and Doré, K.A. (2017) IgY: A Key Isotype in Antibody Evolution. Biological Reviews of the Cambridge Philosophical Society, 92, 2144-2156. https://doi.org/10.1111/brv.12325

[13] Petry, V., et al. (2012) Bacterial Skin Colonization and Infections in Patients with Atopic Dermatitis. Anais Brasileiros de Dermatologia, 87, 729-734. https://doi.org/10.1590/S0365-05962012000500010

[14] Christensen, G.J. and Brüggemann, H. (2014) Bacterial Skin Commensals and Their Role as Host Guardians. Beneficial Microbes, 5, 201-215. https://doi.org/10.3920/BM2012.0062

[15] Tsukamoto, Y., Nishiura, K., Ryu, H. and Maeda, O. (2017) Development of Ultraviolet Radiation Care Products Using Ostrich Antibodies. Fragrance Journal, 45, 30-34.

[16] Jinnestål, C.L., Belfrage, E., Bäck, O., Schmidtchen, A. and Sonesson, A. (2014) Skin Barrier Impairment Correlates with Cutaneous Staphylococcus aureus Colonization 
and Sensitization to Skin-Associated Microbial Antigens in Adult Patients with Atopic Dermatitis. International Journal of Dermatology, 53, 27-33. https://doi.org/10.1111/ijd.12198

[17] Bunikowski, R., Mielke, M.E., Skarabis, H., Worm, M., Anagnostopoulos, I., Kolde, G., Wahn, U. and Renz, H. (2000) Evidence for a Disease-Promoting Effect of Staphylococcus aureus-Derived Exotoxins in Atopic Dermatitis. Journal of Allergy and Clinical Immunology, 105, 814-819. https://doi.org/10.1067/mai.2000.105528

[18] Wichmann, K., Uter, W., Weiss, J., Breuer, K., Heratizadeh, A., Mai, U. and Werfel, T. (2009) Isolation of Alpha-Toxin-Producing Staphylococcus aureus from the Skin of Highly Sensitized Adult Patients with Severe Atopic Dermatitis. British Journal of Dermatology, 161, 300-305. https://doi.org/10.1111/j.1365-2133.2009.09229.x

[19] Breuer, K., Haussler, S., Kapp, A. and Werfel, T. (2002) Staphylococcus aureus: Colonizing Features and Influence of an Antibacterial Treatment in Adults with Atopic Dermatitis. British Journal of Dermatology, 147, 55-61. https://doi.org/10.1046/j.1365-2133.2002.04872.x

[20] Lebon, A., Labout, J.A.M., Verbrugh, H.A., Jaddoe, V.W., Hofman, A., van Wamel, W.J.B., van Belkum, A. and Moll, H.A. (2009) Role of Staphylococcus aureus Nasal Colonization in Atopic Dermatitis in Infants. Archives of Pediatrics and Adolescent Medicine, 163, 745-749. https://doi.org/10.1001/archpediatrics.2009.117

[21] Bessa, G.R., Quinto, V.P., Machado, D.C., Lipnharski, C., Weber, M.B., Bonamigo, R.R. and D'Azevedo, P.A. (2016) Staphylococcus aureus Resistance to Topical Antimicrobials in Atopic Dermatitis. Anais Brasileiros De Dermatologia, 91, 604-610. https://doi.org/10.1590/abd1806-4841.20164860

[22] Na, S.-Y., Roh, J.-Y., Kim, J.-M., Tamang, M.D. and Lee, J.-R. (2012) Analysis of Colonization and Genotyping of the Exotoxins of Staphylococcus aureus in Patients with Atopic Dermatitis. Annals of Dermatology, 24, 413-419. https://doi.org/10.5021/ad.2012.24.4.413

[23] Schafer, F., Fich, F., Lam, M., Gárate, C., Wozniak, A. and Garcia, P. (2013) Antimicrobial Susceptibility and Genetic Characteristics of Propionibacterium Acnes Isolated from Patients with Acne. International Journal of Dermatology, 52, 418-425. https://doi.org/10.1111/j.1365-4632.2011.05371.x

[24] Loeffler, A. and Lloyd, D.H. (2018) What Has Changed in Canine Pyoderma? A Narrative Review. The Veterinary Journal, 235, 73-82. https://doi.org/10.1016/j.tvjl.2018.04.002

[25] Stefanetti, V., Bietta, A., Pascucci, L., Marenzoni, M.L., Coletti, M., Franciosini, M.P., Passamonti, F. and Proietti, P.C. (2017) Investigation of the Antibiotic Resistance and Biofilm Formation of Staphylococcus pseudintermedius Strains Isolated from Canine Pyoderma. Veterinaria Italiana, 53, 289-296.

[26] Dowling, P.M. (1996) Antimicrobial Therapy of Skin and Ear Infections. The Canadian Veterinary Journal, 37, 695-699. 